\title{
Role of France in Solution of the "Eastern Questions" and Its Influence on Ottoman-French Relations (XVIII-XIX)
}

\author{
Kalkaman Tursunovich Zhumagulov ${ }^{1} \&$ Nurzhigit Momynbekovich Abdukadyrov $^{1}$ \\ ${ }^{1}$ Al-Farabi Kazakh National University, Almaty, Kazakhstan \\ Correspondence: Nurzhigit Momynbekovich Abdukadyrov, Al-Farabi Kazakh National University, Al-Farabi av, \\ 71, 050038, Almaty, Kazakhstan.
}

Received: February 28, 2015

Accepted: March 20, 2015 Online Published: April 24, 2015

doi:10.5539/res.v7n6p138

URL: http://dx.doi.org/10.5539/res.v7n6p138

\begin{abstract}
In the period of XVIII-XIX centuries, in the course of solving the "Eastern questions", France, as well as the other European imperialist countries, had particularly political principles, and interfered in the internal affairs of political and economic weakened Ottoman Empire. In the nineteenth century, in the division of the territory of the Ottoman Empire between the other European empires to address the "Eastern questions", France also had its own political plans. This article discusses the role of France in solving "Eastern questions", which became the core of the major political problems in international relations and its influence on Ottoman-French political relations. The main scientific objective of this paper is to study the political relations between the Ottoman Empire and France during the emergence of political factors in order to solve the political problems in the framework of the "Eastern questions" in the period of XVIII-XIX centuries.
\end{abstract}

Keywords: the Ottoman Empire, Eastern questions, Asia, Near East, France, European countries, geopolitics, diplomacy

\section{Introduction}

In the 90s of the eighteenth century, in Europe, was the rise of Napoleon Bonaparte, who carried out several acts of aggression in Europe. Over time, the major political achievement of Napoleon Bonaparte was the conquest of Venice in the Northern Italy in 1797, on the border with the Ottoman Empire. Continuing his aggressive gestures to the East, Napoleon threatened to the territories of the Ottoman Empire, such as an Eastern Europe and the Balkan Peninsula. Napoleon Bonaparte started to wake up the idea of independence in the minds of the peoples of the Balkan provinces of the Ottoman Empire. On the basis of which he strengthened the desire for independence of the Balkan people from the Ottoman Empire. Napoleon laid the groundwork for strengthening of especially Greeks and Serbs in the Balkans. Such actions in the Balkans increased the "Eastern questions", which was taking place during the same period in international politics (Fremont-Barnes, 2010). At the same time, one of the most important steps of Napoleon in aggravation of the "Eastern questions" was his acts of aggression, organized against to the Egyptian provinces of the Ottoman Empire. In order to implement the military and political plans, Napoleon Bonaparte organized expansionary activities in the Egyptian provinces of the Ottoman Empire in 1798. To protest against of such actions of Napoleon to the Egypt, the Ottoman Porte (the Ottoman government-author) appropriated an action taken against him and attempted to stabilize the political situation in Egypt (Roberts, 2014).

\section{The Political Influence of France under Napoleon Bonaparte to the Ottoman Empire and Increasing of} the "Eastern Questions"

After the Great French Revolution, spreading the message of independence in the Ottoman Empire's Balkan provinces of France organized by Napoleon and Napoleon's aggressive actions to Egypt drew the attention of the other European empires to the East. Representatives of a coalition against Napoleon Bonaparte's expansionary in Europe, particularly Russia and the United Kingdom shot troopers in the eastern part of the Mediterranean Sea. Napoleon was forced to retreat back had noticed it. At the same time, the expansion of Napoleon Bonaparte to Egypt broke relations of friendship that has lasted for centuries. Also the most important was his contribution to the increasing of the "Eastern questions", which had become a topic in international relationship. It is important to mention the fact that the United Kingdom was one of the empires against France, the United Kingdom feared of France's possession of Egypt, the Eastern part of the Mediterranean Sea and the Red Sea areas, and did not 
want to move that regions to France (Anderson, 1982). The Ottoman-English Agreement was signed in order to restrict the actions of France in Egypt. France in turn began working on an agreement with allies as soon as had known about it (Beydilli, 1999). Thereafter the Ottoman Empire, the United Kingdom and France adopted an Alexandria Contract in 1801. As a result of the Contract which was concluded between French General Menow and Allied generals, France withdrew the troops from Egypt and returned the occupied territories and the prisoners to the Head of Egypt (Uçarol, 1995). Russia was against Napoleon's acts of aggression in Egypt too, and did not wish strengthening of Napoleonic France not only in Europe but also in the Mediterranean Sea. Because, at that time Russia had a plan to get out of the Mediterranean Sea. On the basis of that Russian-Turkish Agreement adopted in 1898, and Russia sent its warships to limit the number of Napoleon's attempts in Egypt.

Taking such political steps of France to Egypt and easy taking over Egypt by force showed the weakness of the Ottoman Empire. Had seen that European states changed their political views to the Ottoman Empire, and all the Western states began the conflicts over the Eastern area of the Ottoman Empire. Such factors were the basis for the further aggravation of the "Eastern questions" (Lewis, 1995). One of the most important consequences of the expansion of Napoleon was stagnation of the Ottoman-French relations that had endured through the centuries. At the same time, one of the most important results was establishment of the political agreements between the Ottoman Empire and the main contenders in the French foreign policy, Russia and the United Kingdom. Through the support of the United Kingdom and Russia, the Ottoman Empire had achieved good results. And France was deprived of his political reputation on the (Shaw \& Kural, 1977) Mediterranean Sea.

Political, economic weakness of the Ottoman Empire claimed that the European empires as the United Kingdom, Austria and Russia began to put pressure on all sides of the territory of the Ottoman Empire at the beginning of the nineteenth century. The main political goal was the Ottoman Empire's internally deconstruction and the possession for its territories. To get out of such political situation the Ottoman Empire was forced to re-rapprochement with France (Karal, 1946). On the basis of such a policy Sultan Selim III strengthened the relationship with France by their ambassadors and diplomats and became friendly with France again. As a result, the agreement had been signed between the Ottoman and French ambassadors in Paris in 1802. One of the most important aspects of the agreement was to revive a long-standing relationship. At the same time, there were terms of helping to maintain the territorial integrity between the Ottoman Empire and France. After the restoration of political relations with France, the Ottoman Empire had tried to different political steps to save territories in the Balkans and the East from Europeans. After the political relations between the two countries renewed, Napoleon asked to recognize newly established authority of Napoleon Bonaparte to the Head of the Ottoman Empire Selim III in 1804. At the time, the Ottoman Empire was enthusiastic about the recognition mode of Napoleon in France, but the United Kingdom and Russia opposed to recognizing Napoleon Bonaparte's sovereignty by the Ottoman Empire (BOA, 6600). Under the rule of fear of installation of France in Europe and its political control over the Balkans and the Eastern territory of the Ottoman Empire, the United Kingdom and Russia concluded a mutual friendship agreement in London in 1805. This alliance was formed against France, as well as the development issues of the Eastern area were considered there. Because, the acquisition of the Eastern part of the Mediterranean Sea, the Near East and the Balkans was the part of the plan on the agenda of the European empires, each of them had attempted to achieve these areas as soon as possible. According to it, Russia was going to enter the Mediterranean via the Aegean Islands and Straits, the United Kingdom was planning to get out of the Indian Ocean through Egypt and the Red Sea. In order to prevent such actions of allies, the Ottoman Empire decided to act together with France. This was agreed with the French authorities in order to protect the own interests in the East, together with the Ottoman Empire they planned to keep off Russia and the United Kingdom from that areas. On the basis of it the French were going to hit the south of Russia, and had pumped into the war the Ottoman Empire against Russia. France declared open the political and military support to the Ottoman Empire. On the basis of political and military support of France the Ottoman Empire declared war on Russia in 1806. And France in turn opened war on Russia on the other hand, and Russia was forced to fight on two fronts (Chandler, 1995). In June of 1807 in Friesland having been hitten by the French the Russians were forced to ask for the truce. As a result, in July of 1807 between the Emperor Alexander I and Napoleon was concluded the Tilsit Agreement. According to Tilsit Agreement, France and Russia agreed not to fight, Russia and the Ottoman Empire remained in the open war in turn. Russia had a large military force at this time and the Ottoman Empire would not only go against it with such weak economic power (Finkel, 2005). Also there was signed one more agreement between Napoleonic France and Russia in 1808 in Erfurt, it made friendly France and Russia more. But the war between Russia and the Ottoman Empire had been continued. After Erfurt Agreement Russia and France would not fight each other, on the contrary, in accordance with this agreement Napoleon offered to Russian Head to pull the territories of the Ottoman Empire, Wallachia and Moldova. This action of Napoleon was unjust; it was the basis for the aggravation of the "Eastern questions". However, Russia 
did not agree it once, and continued to plan for military and political actions through the own territories in Greece to get to the Mediterranean Sea (Stephen, 1982).

\section{Greece Problem and Political Position of France}

At the beginning of the nineteenth century Sultan of the Ottoman Empire was Selim III, his leading came to the depressive phase of foreign policy of the empire. Despite this, Selim III tried to solve political problems of the foreign policy of the Empire through diplomatic channels, he had opened embassies in several countries. On the basis of that good external relations had been established with European countries. However, at this period, the "Eastern questions" were increased and European countries such as the United Kingdom, France, Russia, Austria began to put the pressure on the territory of the Ottoman Empire in order to solve it. The United Kingdom in turn wished take over the Ottoman Empire's trade routes in the Eastern part of the Mediterranean Sea, Egypt and the Near East, France wanted to acquire African and the Near Eastern provinces of the Ottoman Empire. Russia did not lag behind in the process, and through the ownership of the Caucasus area and straits around the Istanbul planned to get out of the Mediterranean Sea. And Austria in turn planned the acquisition of the Balkan provinces of the Ottoman Empire, and thus, wanted to get out of the Mediterranean Sea. Based on these plans, since the first quarter of the nineteenth century we can see intensification of fighting of European empires for the territory of the Ottoman Empire. Thus, the "Eastern questions" were gotten even worse, weakened political and economic spheres of the Ottoman Empire could not resist to fighting for the territories in the Near East and Africa, as well as Eastern European area between the European empires (Hourani, 1991).

Such debates of the European empires from the twenty years of the nineteenth century increased the pressure on the foreign policy of the Ottoman Empire. France also had a strong role in this matter. Beginning of the Greek uprising in 1821 attracted the attention of the European empires (Turan, 1951). The European empires were fully supported the "freedom" of the nations composed of the Ottoman Empire, and tried to provide social and moral support to the Greeks. There were conducted negotiations between the United Kingdom and Russia in St. Petersburg in 1827 for such of the purposes, and as a result, the Autonomy of Greece had begun to demand from the Ottoman Empire (Mantran, 1989). There were considered the issue of Greece as part of the Ottoman Empire, the right to tax and other revenue collection of the Ottoman government, and not intervention in the internal affairs of Greece. France immediately supported such proposals of the United Kingdom and Russia. However, the Ottoman government rejected such political radical recommendations of the European countries (Nina, 1989). Thus, the Greek problem became the main issue of the "Eastern questions" and the French had been kept friendly relations for a long time, came to be an allie of the European empires. The Ottoman Government began to finalize the uprising on the territory of the Greeks and planned to join fleet equipped in Egypt and Anatolia to go to the military action. According the plan it landed at the Navarin Cape located in the south-west of the Peloponnese Peninsula of Ion Sea. Under the Petersburg Agreement concluded between Russia, the United Kingdom, France on the Autonomous Independence of Greece in 1827, the Allies demanded to leave Greece of the allies' fleet in the Navarin Cape. In response, the Egyptian and the Turkish combined fleet began military actions against the Allies' fleet (France, the United Kingdom, Russia), and they went to the war in the Navarin Cape. The dominant power at this war was of the Turkish-Egyptian fleet, it had 90 ships, 16 thousand sailors. But very well organized Russian, English, French squadrons had won them. The defeat of the Turkish-Egyptian fleet even more aggravated political relations between the Ottoman Empire and the Allies (Andrienko, 2002). Greek problem later in 1828-1829 became the reason of the Russian-Turkish War, and the Ottoman Empire were defeated in this war. France supported Russia in this war. The main goal of France was using the defeat of the Ottoman Empire. After the end of the Russian-Turkish War (Bitis, 2006), political interests of France in the Eastern territory of the Ottoman Empire did not stop. On the basis of that, the French stared of the Eastern provinces of the Ottoman Empire, which were weakened of war. The "Eastern questions" were a reason for the French plans for the implementation.

\section{Political Actions of France at the Northern Africa, Its Political Plans on Egypt and the Straits Question}

There were political and also economic reasons of activity of France for the decision of the "Eastern questions". With the help of the influence of the Levant, the French trade company in the east of the Ottoman Empire, the French created a lot of centers of trade, developed trade business before, and then they planned development of trade in the Near East and Northern African parts of the empire. In light of increasing global imperialism, France was active too, and it wished the acquisition of Algerian province in the Northern Africa of the weakened Ottoman Empire. To this end, the French invaded Algeria in June of 1830. The main cause of the French accession into the territory of Algeria was the favorable geographical position of Algeria which was situated on the Mediterranean coast and was perfect for the development of trade (Kuran, 1957). French invading into Algeria in order to solve the "Eastern questions" was one of the most serious political kicks against the Ottoman 
Empire, and it had become the end for the allied relationship which was continued throughout the centuries. Thus, in the framework of the "Eastern questions", the European empires began invasion to the Balkans and Eastern provinces of the Ottoman Empire, which had accelerated the French colonization of Algeria. The French colonization of Algeria was carried out on the basis of such unjust actions of the imperialist reasons. So the French unfair colonization of Algerian provinces of the Ottoman Empire was one of the most important political factors of the "Eastern questions".

Different political problems took place in foreign policy and domestic politics of the Ottoman Empire in the 30-40 years of the nineteenth century. There were the political problems on the "Eastern questions", and the political uprising of Egyptian vicegerent Mehmet Ali Pasha against the Ottoman government started in 1831. Mehmet Ali Pasha with a view to the creation of the individual power in Egypt in 1831-1833 had been faced a number of areas of the provinces of Syria and Anatolia (Hourani, 2004). In a short time it had become the uprising of international importance. With regard to its causes and course the uprising started, and had been feared of Mehmet Ali Pasha's military actions, the Ottoman Sultan Mahmud II began to ask for military assistance of the European empires. However, the European countries decided not to involve such matters in the internal policies of the Ottoman Empire at that time. Trying to stifle the uprising by whatever means Sultan Mahmud II looked for allies. Finally, the Russian Empire expressed readiness to render the political and military support to the Ottoman Empire and the Hunkar-Iskelesi Political Agreement was concluded between the two Empires in 1833. According to this agreement, Russia would help to quell the uprising and instead had the right to get out the trade and military ships to the Mediterranean Sea through the Black Sea, Istanbul and Straits. The United Kingdom, France and other European empires did not like such political plans of Russia and they had to intervene these actions (Aksan, 2007). Thus, the governor of Egyptian province of the Ottoman Empire, Mehmet Ali Pasha's uprising took the international character, and became into one of the most important factors of the "Eastern questions". The Ottoman government was helpless alone in solving such problems had been taken place in its internal policy. European countries did not wish only Russia's intervention in the uprising of Egyptian ruler that is why they agreed to stifle a rebellion in 1839 (Kutluoğlu, 1999). Here the United Kingdom declared the protection of the Ottoman Empire. Because, at that time the United Kingdom had access to the Indian Ocean through the Near Eastern provinces of the Ottoman Empire and was filled with a lot of trade profit. However, France wished the competitiveness on trade, economic and political spheres with the United Kingdom at this time in the East, so it did not want to agree with such political decision of the United Kingdom. On the basis of which, the competition had been increased between France and the United Kingdom in the East, and France supported Mehmet Ali's active moves to an act of war in the East. The French supported Mehmet Ali's political and military actions in the Eastern provinces of the Ottoman Empire, and recognized the ruler of Egypt as an its ally in the East. Thus, some European empires tried to use the ruler of Egypt, Mehmet Ali's rebellion in realizing their political plans (Fahmy, 1997). The French government used the ruler of Egypt to strengthen its political and economic domination in the Eastern part of the Mediterranean Sea. The Egyptians had relied on the political support of the French moved freely in the East. As a result, France created shopping centers and the economic base in Egypt and other regions of the Northern Africa. At the same time, France had strengthened its political position there, and rejected for a long time the political and economic domination of the British in this region (Ufford, 2007). At this point, Russia and other European empires understood the need to suppress rebellion of Egyptian ruler and raised the question to hold a special meeting. Finally, the United Kingdom, Russia, Austria, Prussia and Turkey concluded the London Convention in 1840. The main political issues of the Convention were stopping political actions of Egyptian ruler in the East, which had been continued for almost ten years, and restriction on political activities of France in the East (Aharoni, 2014). The Allies came up against Egyptian ruler Mehmet Ali Pasha, who refused to comply with the requirements of the Convention, and he was subject to the Ottoman sultan. Mehmet Pasha was elected as Vali of Egypt, and Egypt was controlled by his descendants in turn. France had seen the political situation in Egypt, refused to support him, and on the contrary was going to be closer to the European countries.

After the suppression of the ruler of Egypt Mehmet Ali Pasha's political uprising, which was the one of the largest centers of the "Eastern questions", lasted about ten years, in 1840-1841, soon there was raised one more of a political issue in international relations there. This was the "Straits question" of the European empires. The Straits question could not be one of the large problems of "Eastern questions", but in turn became the basis for the birth of the most important political issues (Christos, 1987). Entering of the European military ships to the Ottoman Empire's Straits was the cause of the birth of the Straits question. Among them were French vessels too, they were to be carried out by the French political and economic plans in the Near East. Austria began to join it too. However, the United Kingdom provided own political influence in the East and did not want to share with anyone the Near East (Hale, 2000), and it was trying not to let France here, and held talks with the Ottoman 
Empire and Russia. Then, the Conference organized on the Straits in London in 1841, and France, the United Kingdom, Russia, Prussia and Austria participated in it. By the decision of the Conference, any of the military ships of any country would not enter the Ottoman Empire's Straits (Hanığlu, 2008).

\section{The Ottoman-French Alliance in the Crimean War}

After finding the decision on the Egyptian and the Straits questions raised in the beginning of the 40s of the nineteenth century, as a result of political unrest and revolutions that took place in European countries, "Eastern questions" calmed down for about ten years. However, in the early 50s, the "Eastern questions" was growing again, and one of the main engines of it was Russia. In the 40s Russia assisted in solving various political problems in Europe, had a reputation in international politics, fixed its political position in the Eastern Europe, and after the entry into the Balkan territory of the Ottoman Empire began threatening to the Balkan provinces (Figes, 2010). Russia was one of the most powerful empires in Europe at that time, it was trying to strengthen its political influence in Europe and all over the world. First of all, by helping the independent survival of the Orthodox peoples in the Balkan provinces of the Ottoman Empire, Russia undertook to strengthen the rule of Russia in the Balkans, and secondly, (Royle, 2000) taking care of their most sacred places of Christianity in the Near East, tried to get out to the East and the Mediterranean Sea. However, France opposed Russia's plans of the hosting in Palestine and to take care of the holy places of Christianity in the region firstly at that time. This problem was caused by more than a century ago (Solov'ev, 2003). Regardless of any opposition of the Europeans, Russia refused to give up the realization of the "religious" plans. To "take care" of the holy places in the Near East among the countries followed the Catholic direction of Christian religion began to France, and two states expressed their political proposals for the implementation of the objectives to the Ottoman Empire. According to the Agreement concluded in 1740, the Ottoman Empire allowed to take care of the holy places in Palestine to France. Russia had been rested of the political plans outside, and it reminded of requirements to the Ottoman Empire once again through the threating to the provinces of Wallachia and Moldova. However, had been supported by the United Kingdom and France, the Ottoman Empire refused to comply with such requirements of Russia. After that, Russia exerted the political pressure on the provinces of the Ottoman Empire, Wallachia and Moldova, and occupied them in the summer of 1853 (Kezban, 2006). Then, in order to implement its geopolitical plans under the guise of taking care of the Holy places, began to pressure the Eastern provinces of the Ottoman Empire (Zayonchovskiy, 2002). In order to stop such actions of Russia, the representatives of the United Kingdom, France, Austria and Prussia met in Vienna to take the note to prevent a new war between the Ottoman Empire and Russia, and sent the note to Petersburg and Istanbul. However, the note had not been taken by parties, and as a result, a new war broke out between the two countries. It was the Crimean War in the period of 1853-1856, which was called as the "Eastern War" in international politics. At the time, the Ottoman Empire based on the political support of France and the United Kingdom and declared war on Russia in October, 1853. The War was waged in the direction of the Caucasus and the Danube, in the region of Crimean and Anatolian coasts of the Black Sea (Baumgart, 1999).

Arised between the Ottoman Empire and Russia, the Crimean War was one of the largest wars worsened the "Eastern questions", and had become an international one. France was involved in the war too, it was an ally of the Ottoman Empire during the War (BOA. İ. HR. no:6592/4 1856). France gave to the Ottoman Empire military support in fighting in the Danube and the Black Sea, as well as financial aid during the war. The Crimean War was completed with the Paris Agreement in 1856, where Russia acknowledged its defeat. The Ottoman Empire, thanks to the help of France and the United Kingdom, achieved the same results. However, the Crimean War in the East was the largest event but it was not able to provide a completly solution of the "Eastern questions" (BOA. A. DVN. NMH dos 8, göm 9, 10,11 1856). During the war, the Ottoman-French relations were good to the extent that their relationship continued after the end of the war. At the same time, France had established a good relationship with the Ottoman Empire, because of its political plans, it operated freely as well as the United Kingdom in the Near East, carried out the trade-economic and political plans there.

\section{Political Position of France on the Problems of the Near East and the Balkans}

After the end of the Crimean War, the Ottoman Empire began its economic recovery had been weakened by the war. In which various reforms had been carried out, on the basis of a loan from the capitalist world leader-countries, such as the United Kingdom, France in 1854-1855, (PRO, FO 78/854), there was created the Ottoman Empire State Bank. Unprecedented economic measures had been implemented in the country (PRO, FO 195/460). Named above the European empires, through the loaning the Ottoman Empire, implemented their capitalist policies. However, the continuous process of obtaining a loan from the countries of Europe led the Ottoman Empire to the economic dependence to the European countries in the 60-70s of the nineteenth century. The European states set their financial requirements to the Ottoman Empire and would like to take it to their own 
political dependence, instead of its loans took the raw materials from African and the Near Eastern provinces more and more (PRO, FO 195/460). As a result, the European countries, including France, carried out on their own various economic projects in the provinces of the Empire in the Near East and Africa. One of them was the Suez Canal, but it caused the conflict between the Europeans. These conflicts between the European countries for the territory of the regions of the Ottoman Empire in turn, had become a factor of the "Eastern questions" (Karabell, 2003). The Ottoman Empire was not able to solve such political issues alone. The Empire was limited to tax only in the regions. France was in political conflicts with other European countries to strengthen the position in the Northern Africa and the Near East. Among them was the main rival of France, the United Kingdom, and the end result of the long years of war was the United Kingdom's ownership of the Suez Canal and Egypt, but France was limited by possession of Tunisia in 1881-1883. France's ownership of Tunisia was carried out within the framework of the solution the "Eastern questions".

The peoples of the Balkan provinces of the Ottoman Empire, Bulgarians, Serbs, Bosnians, Montenegrin and others in 1870 uprised for the independence and against taxes imposed by the Ottoman government, and the majority of them was ruthless suppressed (Abdukadyrov et al., 2014). As noted above, these factors had an international character, and Russia, Austria, Great Britain, France and other European countries participated in it. Intervention of the European empires to the internal affairs of the Ottoman Empire for the Balkans problem was the main topic of the "Eastern questions" in the 70s. Austria and Russia were involved actively in the Balkan issue among the European empires. The United Kingdom interfered in it, in order to protect the own political interests in the Black Sea and Straits. However, France did not actively involve in the Balkan issue, which has become the main theme of the "Eastern questions". It participated to the international conferences (Istanbul, 1876; London, 1878; Berlin, 1878), which was organized in order to consider the Balkan issue within the framework of the "Eastern questions" only, but did not participate so actively in the conflicts for the Balkan peoples and territories like other European empires, and did not show a significant political pressure against the Ottoman Empire.

\section{Conclusion}

In general, the external relation between France and the Ottoman Empire was a different level due to the increased time of the "Eastern questions" in the period of the XVIII-XIX centuries in international politics. As an example we can mention the next, in spite of France's ownership of Algeria in the 30s of the nineteenth century, it supported the Ottoman Empire in the Crimean War. Despite France took part in resolving the "Eastern questions" as the European imperialist state, but had not such a great activity like the United Kingdom. France was often only sought to exercise its political and economic plans in the East. In spite of France's possession of the provinces of the Ottoman Empire in the Northern Africa, such as Algeria, Libya, was not interested in removing the Ottoman Empire as soon as possible like Austria and Russia under the guise of the "Eastern questions". Therefore, France did not support the final departure decision of the Ottoman Empire in each of the international sets organized in the framework of the solving the "Eastern questions". The causes of providing the Ottoman Empire's Egyptian, Algerian, Tunisian provinces of the political pressure by the French each of year were the French Empire's imperialist plans on the one hand, and the solving of the "Eastern questions" on the other hand.

\section{References}

Abdukadyrov, N. M., Bedelova, G. S., \& Kozhabekova, Z. B. (2014). Taxes and tributes of Bosnia and Herzegovina charged by the Ottoman Empire in the 50-ies of the XIX century. Life Science Journal, 11(9).

Aharoni, R. (2014). The Pasha's Bedouin: Tribes and state in the Egypt of Mehemet Ali, 1805-1848 (p. 277). London: Routledge.

Aksan, V. H. (2007). Ottoman Wars 1700-1870: An Empire Besieged (p. 375). London: Pearson Education Limited.

Anderson, M. S. (1982). The Eastern Question. London: Macmillan.

Andrienko, V. G. (2002). Do i posle Navarina (p. 510). S-Peterburg: Terra Fantastica.

Baumgart, W. (1999). The Crimean War 1853-56 (Modern Wars, p. 256). USA: Bloomsbury.

Beydilli, K. (1999). “Küçük Kaynarca'dan Yıkılışa”, Osmanlı Devleti Tarihi, İstanbul. Feza Gazetecilik A. Ş.

Bitis, A. (2006). Russian and Eastern question. Army, Government, and Society. British Academy (p. 542) Oxford university press.

BOA. A. DVN. NMH. dos. 8, göm. 9. 10. 11. 1856; Dîvân-1 Hümâyûn ve Name-i Hümayun Defterleri 
(Chancellery of the state apparatus).

BOA. HH. 6600 Hatti-Hümâyûn. (Document Ottoman archive).

BOA. İ. HR - no: 6592/4 1856. Hâriciye Siyasî (Foreign polisy).

Chandler, D. G. (1995). The Campaigns of Napoleon (p. 582). Simon \& Schuster.

Christos, L. R. (1987). The Turkish Straits. Leiden: Martinus Nijhoff Publishers.

Fahmy, K. (1997). All the Pasha's Men: Mehmed Ali, His Army and the Making of Modern Egypt (p. 318). Cambridge: Cambridge University Press.

Figes, O. (2010). Crimea: The Last Crusade (p. 608). London: Allen Lane.

Finkel, C. (2005). Osman's Dream: The Story of the Ottoman Empire 1300-1923 (p. 286). New York: Basic Books.

Fremont-Barnes, G. (2010). Napoleon Bonaparte (p. 64). Oxford: Osprey Publishing Ltd.

Hale, W. (2000). Turkish Foreign Polisy (pp. 1774-2000). London: Frank Cass.

Hanığlu, Ş. M. (2008). A Brief History of the Late Ottoman Empire (p. 241). Princeton: Princeton University Press.

Hourani, A. (1991). A History of the Arab Peoples (p. 576). London: Faber \& Faber, Limited.

Hourani, A. (2004). The Modern Middle East: A Reader (p. 71). University of California Press.

Karabell, Z. (2003). Parting the Desert: The Creation of the Suez Canal (p. 310). Knopf.

Karal, E. Z. (1946). Selim III'ün Hatt-ı Hümayunları. Ankara.

Kezban, A. (2006). Başlangıçtan 1917 Bolşevik Devrimi'ne Kadar Rusya Tarihi (p. 318). Ankara.

Kuran, E. (1957). Cezayir'in Fransızlar Tarafindan işgâli Karşısında Osmanlı Siyaseti (1827-1847). İstanbul.

Kutluoğlu, M. H. (1999). Tanzimat Dönemi Osmanlı Dış Politikası ve Diplomasisi. Çağda Türk Diplomasisi: 200 Ylllık Süreç. Ankara.

Lewis, B. (1995). The Middle East: 2000 Years Of History From The Birth Of Christianity. London: Weidenfeld-Nicolson.

Mantran, R. (1989). Histoire de l'empire ottoman (p. 802). Paris: Fayard,

Nina, M. A. (1989). French Images from the Greek War of Independence (1821-1830): Art and Politics Under the Restoration (p. 176). Yale University Press.

PRO, FO Public Records Office. Fond Foreign Office. London.

PRO, FO 195/460 doc.entitled 1856. Proposals for making a National Bank in Turkey.

PRO, FO 195/460, Layard to Stratford de Redcliffe, London 1856. Directors of Ottoman Bank to Yvan and Ede. London 1856.

PRO, FO 195/460, prospectus of the Ottoman Bank. London 1856.

PRO, FO 78/854, Stratford Canning to Palmerston, Constantinople.

Roberts, A. (2014). Napoleon the Great (p. 976). London: Penguin.

Royle, T. (2000). Crimea: The Great Crimean War, 1854-1856 (p. 592). Palgrave Macmillan.

Shaw, S. (1977). History of the Ottoman Empire and Modern Turkey (Vol. 2). Cambridge: Cambridge University Press. http://dx.doi.org/10.1017/CBO9780511614972

Solov'ev, S. M. (2003). Vostochniy vopros (p. 313). Moskva.

Stephen, J. L. (1982). Aspects of European History, 1789-1980 (p. 374). London: Routledge.

Turan, Ş. (1951). 1829 Edirne Antlaşmasl, 111.

Uçarol, R. (1995). Siyasi Tarih (1789-1994), İstanbul. Filiz Kitapevi.

Ufford, L. W. (2007). The Pasha: How Mehemet Ali Defied the West, 1839-1841 (p. 271). Jefferson: McFarland.

Zayonchovskiy, A. M. (2002). Vostochnaya voyna 1853-1856 (p. 928). S-Peterburg. 


\section{Copyrights}

Copyright for this article is retained by the author(s), with first publication rights granted to the journal.

This is an open-access article distributed under the terms and conditions of the Creative Commons Attribution license (http://creativecommons.org/licenses/by/3.0/). 